DOI https://doi.org/10.36059/978-966-397-113-1/219-236

\title{
ADAPTATION OF UKRAINIAN LEGISLATION TO EU LEGISLATION IN THE FIELD OF CONTRACTUAL INSURANCE RELATIONS
}

\section{Milovska N. V.}

Ukrainian integration into the European Union (hereinafter referred to as the EU) is impossible without national legislation harmonization with the EU legislation being mandatory precondition of successful implementation of European aspirations of our state. However, the adaptation process, having started from the moment of entering into force of Partnership and co-operation agreement between the European communities and their member states, and Ukraine, ${ }^{1}$ according to which the policy to the harmonization of national legislation with the EU legislation and law has been proclaimed, is not so easy, taking into account a large scope of normative material in all primary adaptation fields, one of them is the field of service provision, including insurance services.

The daily life of the state in general, as well as its individual people, is accompanied by certain risks, that is why insurance as a category reflecting a special domain of society relations is one of the most efficient legal instruments ensuring the protection of property interests of natural persons and legal entities from possible costs and losses, caused by property damage or loss due to acts of God, road traffic accidents, nonperformance of obligations by counterparties to the agreement etc. At the same time, insurance as a necessary element of society socio-economic system is not only an institution of ensuring of property interest renewal of natural persons and legal entities due to certain life situations connected with sudden danger, but also one of the most stable source of long-term investment. It is determined by the fact that today there is a great necessity in insurance services along with other types of services.

Currently, the legal regulation of relations in insurance service provision in Ukraine is carried out by Chapter 67 of the Civil Code of

\footnotetext{
1 Про ратифікацію Угоди про партнерство і співробітництво між Україною і Європейськими Співтовариствами та їх державами-членами: Закон України від 10 листопада 1994 р. № 237/94-ВР // Відомості Верховної Ради України. 1994. № 46. Ст. 415.
} 
Ukraine (hereinafter - the CC of Ukraine), $\S 2$ of Chapter 35 of the Commercial Code of Ukraine, the Law of Ukraine "On Insurance", other normative legal acts, by rules of certain types of insurance. Thus, according to Article 1 of the Law of Ukraine "On Insurance", insurance is a type of civil legal relations for protection of property interests of natural persons and legal entities in case of occurrence of certain events (insured events) specified by the insurance contract or current legislation, at the expense of monetary funds, formed by insurance payments of natural persons and legal entities (insurance contributions, insurance premiums) and by income from allocation of money from these funds.

Certainly, in the context of European integration processes, the legal regulation of insurance relations should also be based on the norms of the Law of Ukraine "On the National Program for Adaptation of Ukrainian Legislation to the Law of the European Union"”3 and recommendations of such organizations as the International Association of Insurance Supervisory Bodies on insurance activity, Organization for Economic Cooperation and Development as well.

A special place in the domain of insurance legal relations is taken by the EU Directives, which contain norms governing relations of insurance service provision. Therefore, in 1973 and 1979, EU Life Insurance Directives (Directive 73/239/EEC and Directive 79/267/EEC), which have formed the common legal framework for insurance in the EU and are called "first-generation directives", were adopted. The next step towards the development of European insurance legislation was the adoption of "second-generation directives", the main goal of which was the introduction of the principle of freedom as for service provision at the territory of the EU member states. A "single license" for insurance of certain categories of risks, the rules for choosing the law applicable to an insurance contract as well as division of risks for large risks and mass ones was introduced ${ }^{4}$.

\footnotetext{
${ }^{2}$ Про страхування: Закон України від 7.03.1996 р. // Відомості Верховної Ради України. 1996. № 18. Ст. 78.

3 Про Загальнодержавну програму адаптації законодавства України до законодавства Європейського Союзу: Закон України від 18 березня 2004 р. № 1629-IV // Офіційний вісник України. 2004. № 15. Ст. 1028.

4 Пацурія Н. Б. Правове регулювання страхування та роздрібних фінансових послуг в Свропейському Союзі та в Україні: порівняльно-правовий аналіз / Пацурія Н. Б., Безручко Ю. А., Бєлова О. А. К.: Центр учбової літератури, 2007. С. 5.
} 
In 1992, the "third-generation directives" came into force for insurance other than life insurance (92/49/EEC), as well as life insurance (92/96/EEC). They finally consolidated the principles of freedom of institution and freedom of service provision proclaimed in Rome Treaty in $1957^{5}$ : insured party's right to choose any insurer registered in any EU member state as well as insurance companies' right to conclude insurance contracts in any EU member state ${ }^{6}$. Moreover, in the field of insurance, Directive 2000/26/EC of the European Parliament and of the Council "On the approximation of the laws of the Member States relating to insurance against civil liability in respect of the use of motor vehicles holders and obligation performance concerning insurance of such liability" was adopted on May 16, 2000, ${ }^{7}$ as well as the Directive 2001/17/EC of the European Parliament and the Council on reorganization and winding up of insurance undertakings on March 19, 2001 ${ }^{8}$.

It should be mentioned that the system of European law in general is a combination of two interrelated legal subsystems - the integration law and national legislation ${ }^{9}$. At the same time, the EU law closely interacts with international law, the norms of which are enshrined in the constituent treaties on the EU, treaties on the accession of new states to these associations, agreements concluded by the EU with other subjects of international law ${ }^{10}$. Therefore, integration into European and world insurance markets, proclaimed by a national lawmaker, determines the influence and the entry of international law into the field of insurance of our country, absorbing many elements of the world insurance market: terminology, customs, types, insurance rules, etc.

\footnotetext{
5 Договір про створення Європейського економічного співтовариства від 25 березня 1957 р. // Інформаційно - правова система ЛІГА:ЕЛІТ.

${ }^{6}$ Ищенко Н. Г. Страховое право EC: система, источники, основные направления развития. URL: http://www.eurasialegal.info/index.php?option=com_content $\&$ view=article\&id=4542:2015-05-28-11-5144\&catid=195 2013-02-04-08-49-35\&Itemid=2 (дата звернення: 04.05.2019).

7 Директива 2000/26/ЄС Європейського Парламенту та Ради «Щодо зближення законів державчленів стосовно страхування цивільної відповідальності власників транспортних засобів та виконання зобов'язання про страхування такої відповідальності» від 16.05 .2000 p. URL: http://zakon4.rada.gov.ua/laws/show/994_280 (дата звернення: 04.05.2019).

${ }^{8}$ Директива 2001/17/ЄС Європейського Парламенту та Ради «Про реорганізацію та ліквідацію страхових підприємств» від 19.03.2001 p. URL: http://zakon3.rada.gov.ua/laws/show/994_225 (дата звернення: 04.05.2019).

${ }^{9}$ Озернюк Г. В. Міжнародні джерела страхового права країн $Є С$ // Прикарпатський юридичний вісник. 2016. Випуск 6 (15). С. 192.

${ }^{10}$ Татам А. Право Європейського Союзу: підручник. Пер. $з$ англ.; ред. В. І. Муравйов. К.: Абрис; Будапешт: COLPI/OSI, 1998. 423 c.
} 
On June 27, 2014, the economic part of the "Association Agreement between Ukraine, on the one hand, and the European Union, the European Atomic Energy Community and their member states on the other hand" was signed during the meeting of the EU Council ${ }^{11}$. Section IV of this Agreement contains provisions defining normative-legal framework for all financial services subject to liberalization (Subsection 6, Financial Services). The Agreement includes, among others, insurance and insurance-related services, in particular, insurance mediation to financial services. On September 16, 2014, the Verkhovna Rada of Ukraine and the European Parliament simultaneously ratified this Agreement ${ }^{12}$. So, it is a source of legal regulation of insurance relations along with the laws of Ukraine.

Taking into account the provisions of the Association Agreement, the aim of harmonization of Ukrainian legislation with the EU law in the insurance field is to provide for an access of all citizens of the EU member states to the widest range of insurance services and to ensure that insurance companies authorized to carry out insurance in the EU member state can operate throughout the EU. In this case, the coordinator of activities on the single insurance market formation is the European Insurance Committee, representing all national unions and associations of insurers ${ }^{13}$.

A legal instrument mediating the process of providing an insurance service under the national law and EU law is an insurance contract. Insurance contracts help in mediation of relations arising between persons interested in insuring their life, property, liability and other property interests that do not contradict the current legislation of Ukraine (the insured party), on the one hand, and those who carry out insurance (insurers), on the other hand.

In the Civil Code of Ukraine, an individual Chapter 67 is dedicated to the insurance contract, which contains provisions general to all types of insurance contracts. Thus, in Article 979 of the Civil Code of Ukraine an insurance contract means an agreement whereby one party (the insurer)

\footnotetext{
11 Угода про асоціацію між Україною, з однієї сторони, та Свропейським Союзом, Свропейським Співтовариством 3 атомно енергії і їхніми державами- членами, 3 іншої сторони. URL: http://www.kmu. gov.ua/ kmu/control/ru/publish/article?art_id=246581344\& (дата звернення: 04.05.2019).

12 Заєць О. М. Реформування інституту страхування України з урахуванням положень Угоди про асоціацію 3 Свропейським Союзом. URL: http://er.nau.edu.ua/ bitstream/NAU (дата звернення: 04.05.2019).

13 Лояк Ф. Єдиний страховий ринок: стан та перспективи // IN RE. 1999. № 4. C. 10.
} 
undertakes, in case of occurrence of a certain event (the insured event), to pay to the other party (the insured party) or to another person specified in the contract, the monetary amount (the insurance payment) and the insured party undertakes to pay insurance payments and to fulfill other terms and conditions of the contract. In turn, according to Article 16 of the Law of Ukraine "On Insurance", an insurance contract is a written agreement between the insurer and the insured party, according to which the insurer undertakes in the event of the insured event to make an insurance payment to the insured or another person specified in the insurance contract in whose favor an insurance contract has been concluded (to provide assistance, to provide service, etc.), and the insured person undertakes to pay insurance payments within certain time limits and to comply with other terms of the contract. The general provisions on insurance apply to various types of insurance contracts in a subsidiary manner, that is, only if the special rules for these contracts do not provide otherwise. At the same time, the detailed regulation of insurance relations does not mean at all that the principle of contract freedom in this field is limited. Most of the rules governing insurance issues have a dispositive nature; they act in the event when the parties have not resolved the relevant issues in a contract.

At the same time, it should be noted that today "the sale of insurance policies" is spread in practice, in which all the terms and conditions of the insurance contract are unilaterally provided by the insurer, the so-called standard forms of the contract (insurance policy) for certain types of insurance. By purchasing such policy, the insured party agrees to the proposed conditions and can not offer own terms of the contract ${ }^{14}$. Thus, an insurance contract is a type of an adhesion agreement. The EU legislation also recognizes an insurance contract as a kind of an adhesion agreement, but at the same time it protects consumers from unfavorable terms of the insurance contract. Thus, Directive 93/13 of the European Union law states that "unfair" terms and conditions of a contract concluded between a service provider and a consumer can not be executed by force in relation to the consumer (for example, through a court), provided that such "unfair terms and condition" were not duly agreed upon by the parties during individual negotiations. The terms and

\footnotetext{
14 Харитонов С. О. Цивільне право України / С. О. Харитонов, О. І. Харитонова, О. В. Старцев. Вид. 3-тє, переробл. і допов. К.: Істина, 2011. С. 380.
} 
conditions of the contract are not recognized as being properly agreed if the consumer of insurance services has received the previously formed text of the contract and has not had the opportunity to change its content ${ }^{15}$.

A feature of the insurance contract is that it belongs to a group of civil legal contracts on service provision. Common features uniting all contractual obligations on service provision in a single group are the object's features: these are intangible services, and in addition, services inseparably connected with the personality of the service provider ${ }^{16}$ (in our case, the provision of insurance services is inseparably connected with the insurer's activity), and the beneficial effect of such activity does not appear in the form of a certain tangible material result, as in the case with contractor agreements, but consists in the very process of providing a service $^{17}$. As V. A. Vasiliev rightly notes, when relations in provision of services lead to establishment of legal rights and obligations and, in this connection, entry into the field of private law regulation, we can talk about legally binding relations, the subject of which is the service ${ }^{18}$. Thus, the insurance contract, as an independent type of contract in the group of contracts on service provision, acts as a legal means to reduce the harmful effects of accidental circumstances provided in the insurance contract (destruction of property, loss of working capacity or death of the insured person, occurrence of other insurance risks). Independence of the insurance contract is an indicator that allows distinguishing it from others, externally similar contracts (agency contract, surety contract, contract of storage, loan, and transportation $)^{19}$.

The peculiarity of the insurance contract is a list of its essential terms and conditions defined by law. So, according to Article 982 of the Civil Code of Ukraine the essential conditions of the insurance contract are: the subject of the insurance contract, the insured event, the amount of money, within which the insurer is obliged to pay in case of the insured event (insured amount), the amount of insurance payment and terms of

\footnotetext{
15 Регулирование договора страхования в рамках права Европейского Союза // Страховое право. 1996. № 2. С. 46.

${ }_{16}^{16}$ Цивільне право України. Особлива частина / За ред. О. В. Дзери. К.: Юрінком Інтер, 2010. С. 318.

${ }^{17}$ Бланд Д. Страхование: принципы и практика. М.: НОРМА, 1998. С. 336.

18 Васильєва В. А. Цивільно-правове регулювання діяльності з надання посередницьких послуг: монографія. Івано-Франківськ: ВДВ ЦІП Прикарпатського національного ун-ту імені Василя Стефаника, 2006. С. 95.

${ }^{19}$ Белоусов Е. Сущность страхования (самостоятельность страхового договора) // Підприємництво, господарство і право. 2002. № 2. С. 23.
} 
payment, the term of the contract and other conditions specified by acts of civil law.

According to Article 982 of the Civil Code of Ukraine one of the most essential conditions of the insurance contract to be agreed necessarily is its subject matter. Without defining exactly the subject matter of the insurance contract, it is not possible to determine its legal nature and content. The lack of a single understanding of the contract subject matter studied can also cause practical problems, including, in particular, the possibility of judicial recognition of contracts as not concluded in which the subject matter has not been clearly defined.

The subject matter of the insurance contract, according to Article 980 of the Civil Code of Ukraine and Article 4 of the Law of Ukraine "On Insurance", may be property interests not contradicting the law and are related to: 1) life, health, working capacity and pension provision (personal insurance); 2) possession, use and disposal of property (property insurance); 3) compensation for damage caused by the insured (liability insurance). However, the determination of the subject matter of this contract, which is such a feature that allows distinguishing it from other contracts, has a contradictory nature and scholars' attitude to such determination of the subject matter is ambiguous. Researchers often only state that the subject matter is one of the essential conditions of the contract, but do not pay due attention to this concept.

The subject matter of any contract is something in which relation person enters in such legal relations and something that they want to achieve. The contract subject matter personifies its legal aim by indicating certain actions with civil law objects (transferring of thing, repairing of a house, manufacturing of products, providing insurance or other services etc. ${ }^{20}$. Therefore, the agreement of the parties to the contract is based on the obligation, which serves as the contract subject matter mediating legal relations between the insurer and the insured regarding the object of their rights. For that reason, the insurance contract subject matter is reduced not only to property interest. The contract subject matter, and more specifically, the subject of obligation arising from the contract, is actions (or inaction) that must be performed by the binding party (or, accordingly, refrain from their performance).

\footnotetext{
${ }^{20}$ Стрижак I. В. Проблема визначення поняття «предмет договору» // Вісник Академії митної служби України. Сер.: Право. 2010. № 2. С. 129.
} 
In A. A. Telestakova's opinion, the contract subject matter on service provision is the service itself $^{21}$. N. V. Fedorchenko also notes that the contract subject matter on service provision is the provision of various services according to customer's order, therefore, the direct activity consisting in performance of certain actions or activities by the executor, as well as the beneficial effect from performance of actions or activities of the executor (the effect is meant), which never takes the form of a new thing $^{22}$. Thus, the insurance contract subject matter is the provision of insurance services by the insurer to the insured parties for the protection of their property interests by making an insurance payment (insurance compensation) in case of the occurrence of a particular event (the insured event) associated with causing damage to the insured, the insured person (in the case of insurance of their life, health, property) or to third parties (in the case of insurance of civil liability of the insured, the insured person).

Among the legal acts regulating the relations for service provision in general, the Law of Ukraine "On Protection of Consumer Rights" deserves special attention. According to paragraph 17, part 1 of Article 1 of this law, the service is the executor's activity on provision (transfer) of material or non-material benefits to the consumer specified by the contract that is carried out by an individual order of the consumers to meet their personal needs.

Taking into account that the insurance services according to the Law of Ukraine "On Financial Services and State Regulation of Markets of Financial Services" on July 12, $2001^{23}$ belong to the types of financial services, their sale is only possible provided that the legal act mentioned is observed. So, according to part 5 of Article 1 of the Law of Ukraine "On Financial Services and State Regulation of Markets of Financial Services" a service is transactions with financial assets carried out in the interests of third parties at their own expense or at the expense of these persons, and in cases provided by law - at the expense of borrowed financial funds from other persons, in order to obtain profit or to maintain the real value of financial assets.

\footnotetext{
21 Телестакова А. А. Правове регулювання відносин з надання послуг. Навч. посіб. К.: Центр учбової літератури, 2010. С. 51.

${ }^{22}$ Федорченко Н. В. Договірні зобов'язання 3 надання послуг: проблеми теорії і практики: монографія. К.: НДІ приватного права і підприємництва НАПрН України, 2015. С. 160.

${ }^{23}$ Про фінансові послуги та державне регулювання ринків фінансових послуг: Закон України від 12.07.2001 р. // Відомості Верховної Ради України. 2002. № 1. Ст. 1.
} 
Attributing insurance services to financial ones corresponds to world standards. Thus, in the General Agreement on Trade of Services (GATS) on April 15, 1994, adopted within the framework of the World Trade Organization, where Ukraine is a member, there is an Annex on financial services $^{24}$. For the purposes of this Annex, a financial service is any service of financial nature offered by a financial service supplier of any member state. Financial services include all insurance services, as well as services related to insurance, banking and other financial services (except insurance ones). At the same time, the European Commission, which is the only body of legislative initiative in the EU, approaches the regulation of financial services systematically and applies the single term the "freedom of financial service provision".

According to the Annex of the General Agreement on Trade of Services, insurance services include the following: 1) direct insurance (including co-insurance): life; not related to life insurance, 2) reinsurance and transfer of part of operations (retrocession), 3) insurance mediation, such as brokerage and agency services; 4) auxiliary insurance services, such as consulting, actuarial, risk assessment and claims (losses) settlement services. For consumer of insurance services, the main services in this list are direct insurance. In Ukraine, these services are provided on the basis of an insurance contract. The rest of the services are such services that ensure a high-quality and guaranteed provision of insurance protection and serve this process to a certain extent, therefore, they form the insurance market.

In Article 125 Association Agreements between Ukraine, on the one hand, and the European Union, the European Atomic Energy Community and their member states, on the other hand, establish the principles of the regulatory framework for all financial services that are subject to liberalization and insurance in particular. It should be noted that in this Agreement, insurance services and their types are fixed in the same manner as in the Annex to the General Agreement on Trade of Services.

Article 125 of Association Agreements between Ukraine, on the one hand, and the European Union, the European Atomic Energy Community

24 Генеральна угода про торгівлю послугами від 15.04.1994 p. URL: http://zakon4.rada.gov.ua/ laws/show/ 981_017/page2 (дата звернення: 05.05.2019). 
and their member states, on the other hand ${ }^{25}$, establishes the principles of regulatory framework for all financial services subject to liberalization and insurance services in particular. It should be noted that in this Agreement, insurance services and their types are consolidated in the same manner as in the Annex to the General Agreement on Trade of Services. In connection with the above, there is a necessity for harmonization of national and international normative legal acts regulating the insurance field, first of all, it refers to the Civil Code of Ukraine and the Law of Ukraine "On Insurance", which does not include the list of insurance services provided in the Agreement.

As O. O. Hamankova notes, the insurance service is the financial service in a form of legally executed obligations with provision of insurance protection which is proposed by insurers to potential insured persons at the market ${ }^{26}$. According to G. O. Ilchenko, insurance service is a set of actions of the debtor (the insurer) aimed at satisfaction of property and non-property interests of consumers of insurance services in case of occurrence of certain events (insured events) defined by the insurance contract, at the expense of monetary funds collected to the insurer's funds by the insured persons' paying of insurance payments and receiving other income by the insurer from allocation, investment or other use of money in these funds ${ }^{27}$.

The typical features of the insurance service, as one of the types of financial services, based on the provisions of the current legislation of Ukraine, are the following: 1) the insurance service is accompanied by movement of financial assets (money), which provides the performing of relevant financial transactions by a service provider (insurer) (their attraction to deposit, in shares, bonds, mortgage certificates, securities issued by the state and other operations provided for in Article 31 of the Law of Ukraine "On Insurance"); 2) the insurance service is an action with financial assets carried out in the interests of third parties; 3) the insurance service is carried out on a paid basis (payment is made before service provision); 4) the insurance service is provided on the basis of the

\footnotetext{
25 Угода про асоціацію між Україною, з однієї сторони, та Європейським Союзом, Свропейським Співтовариством 3 атомної енергії і їхніми державами-членами, 3 іншої сторони. URL: http://www.kmu.gov.ua/ kmu/control/ru/publish/article?art_id=246581344\& (дата звернення: 05.05.2019).

${ }^{26}$ Гаманкова О. О. Ринок страхових послуг України: теорія, методологія, практика: монографія. К. КНЕУ, 2009. С. 79.

${ }^{27}$ Ільченко Г. О. Цивільно-правовий захист прав споживачів страхових послуг: автореф. дис. ... канд. юрид. наук: 12.00.03. К., 2016. С. 10.
} 
insurance contract; 5) the insurance service is a set of financial and accompanying (consulting, actuarial services, services for settling claims (losses) services (operations). In this case, taking into account the provisions of Article 980 of the Civil Code of Ukraine and Article 4 of the Law of Ukraine "On Insurance", types of insurance services are as follows: 1) insurance services in the field of personal insurance, covering property interests of natural persons in relation to life, health, working capacity and pension provision; 2) insurance services in the field of property insurance, where the property interest of the insured is connected with the possession, use and disposal of property, and 3) insurance services in the field of liability insurance, providing insurance protection of property interests, both natural persons and legal entities, connected with possibility of damage to person or property as well as damage caused to a legal entity.

Insurance services are the result of a clearly defined circle of subjects (insurers). The Civil Code of Ukraine defines the insurer as a legal entity specially created for carrying out insurance activity and obtained a license for the insurance activity under the established procedure (Part 1 of Article 984). In order to acquire the status of an insurer, it is necessary to comply with the requirements established by current legislation. Thus, insurance activity in Ukraine is carried out, with a few exceptions, by insurers - residents of Ukraine, which must have at least three participants in its structure. In order to ensure the insurer's solvency and executions of obligations against the insured parties, significant restrictions are imposed on the subject of the insurer's activities, types of insurance, the minimum amount of authorized capital, etc. Thus, the subject of insurer's activity may be insurance, reinsurance and financial activities related to the formation, allocation and management of insurance reserves only ${ }^{28}$.

In addition to commercial insurance companies, the subjects of insurance relations are mutual insurance companies. Thus, natural persons and legal entities for the purpose of insurance protection of their property interests may create mutual insurance companies (Article 14 of the Law of Ukraine "On Insurance"), not aimed at obtaining profit, and therefore, they are not the subjects of entrepreneurial activity. This is the main difference between a mutual insurance company and a commercial

${ }^{28}$ Цивільне право України: підручник: у 2 т. / За заг. ред. В. І. Борисової, І. В. Спасибо-Фатєєвої, В. Л. Яроцького. Київ: Юрінком Інтер, 2007. Т. 2. С. 328. 
insurance organization, for which the provision of insurance protection is a means of obtaining profit ${ }^{29}$.

In the context of the European integration processes taking place in Ukraine, the European experience of legal regulation of non-commercial forms of insurance protection is of great importance. Thus, the operation of mutual insurance companies is regulated by the European Commission Directives, according to which, licenses are not required for mutual companies, in particular, if their activities are of local nature and the annual amount of insurance premiums collected does not exceed 5 million Euro. ${ }^{30}$ However, under the legislation of Ukraine, when carrying out insurance activities without a license, a mutual insurance company can not be considered an insurer, since according to Article 2 of the Law of Ukraine "On Insurance" insurers can be only legal entities in any organizational legal form that have received a license to carry out insurance activities. Licensing of mutual insurance companies is determined by the tasks of the state of preventing the emergence of unfair insurers at the insurance market and ensuring protection of insured persons' interests ${ }^{31}$. At the same time, some researchers consider licensing, the main meaning of which is to control the activities of insurers, as an inappropriate form for non-profit insurance companies which fund is formed on the basis of participants' contributions, and the activity is based on the principles of joint responsibility of members for its results and carried out on a nonprofit basis ${ }^{32}$.

In 2013, the European Commission Advisory Committee presented a report "On the results of research on current situation and perspectives of mutual insurance in Europe", containing proposals for expanding the activities of mutual companies and their mastering of new sectors in the field of insurance services ${ }^{33}$. It should be noted that, at the Western European insurance market insurance cooperatives also operate along

\footnotetext{
${ }^{29}$ Адамов А. С. Історичні аспекти взаємного страхування // Актуальні проблеми держави і права. 2009. Вип. 51. С. 253.

30 Заєць О. М. Реформування інституту страхування України з урахуванням положень угоди про асоціацію з Свропейським Союзом // Правова реформа в сучасних умовах: досягнення і перспективи: VI Міжнар. наук-практ. конф. 26 лютого 2016 р. Т. II. К.: Нац. авіац. ун-т, 2016. С. 265.

${ }^{31}$ Міловська Н. В. Корпоративні відносини у сфері взаємного страхування // Право і суспільство. 2017. № 5-2. С. 84 .

${ }^{32}$ Дадьков В. Н. Взаимное страхование / В. Н. Дадьков, К. Е. Турбина. М.: Анкил, 2007. С. 55.

${ }^{33}$ European Parliament resolution of 14 March 2013 with recommendations to the Commission on the Statute for a European mutual society (2012/2039(INI). URL: http://ec.europa.eu/enterprise/policies/sme/files/ mutuals/prospects_mutuals_fin_en.pdf (Last accessed: 05.05.2019).
} 
with mutual insurance companies, working on the principles of mutual assistance, solidarity, non-profitability as well. The identity of organizations mentioned is also confirmed by the creation of the Association of Mutual Insurers and Insurance Cooperatives in Europe (AMICE), emerged in 2008 on the basis of merger of the International Association of Mutual Insurance Companies (AISAM) and the Association of European Cooperatives and Mutual Insurance Companies $(\mathrm{ACME})^{34}$.

The presence of a large number of non-profit insurance organizations in European countries is determined by the reasons relevant for the Ukrainian insurance market as well, namely: the necessity to obtain insurance services at economically reasonable prices by the insured persons, which is facilitated by absence of a commercial component in relations between insurance participants; the democracy and transparency of activities of mutual insurance organizations, the control of which is exercised by its members; taking of specific risks on insurance, from which commercial insurance companies refuse, as a rule. At the same time, as "Strategy for development of the insurance market of Ukraine for 2012 - 2021" states, the national market problems are increasingly generated by unfair competition, insurance fraud, violation of insurance legislation, etc $^{35}$. In spite of this fact, all grounds for the development of mutual insurance companies exist in Ukraine. Moreover, national scholars justify the necessity of drafting and adopting the Law "On Mutual Insurance Companies" by the Verkhovna Rada of Ukraine, which will provide an opportunity to clearly identify organizational, legal and economic foundations for their creation and activities ${ }^{36}$. Mutual insurance as an alternative to commercial insurance provided by law should help in

\footnotetext{
34 Mutual Insurance in Figures: Executive summary from the 2010 study produced by AMICE's predecessor association, AISAM. Brussels: Association Internationale des Sociétés d'Assurance Mutuelle AISAM, 2010.

${ }^{35}$ Стратегія розвитку страхового ринку України на 2012 - 2021 роки. URL: http://ufu.org.ua/ua/about/ ctivities/strategic_initiatives/5257 (дата звернення: 05.05.2019) (Заголовок з екрану); Тимошенко I. В. Механізм функціонування товариств взаємного страхування і страхових кооперативів: перспективи розвитку в Україні // Науковий вісник Полтавського університету економіки і торгівлі. 2011. № 6 (51), ч. 2. Економіка, організація і управління підприємством. С. 177.

${ }^{36}$ Навроцький С. А. Страховий захист у сільському господарстві: теорія, методологія, практика: автореф. дис. ... док. екон. наук: 08.00.08; Нац. наук. центр «Інститут аграрної економіки УААН. К., 2012. 44 с.; Мачуський В. В. Правове регулювання страхової діяльності в Україні (господарсько-правові аспекти): автореф. дис. ... канд. юрид. наук: 12.00.04. К., 2013. 15 с.; Пацурія Н. Б. Страхові правовідносини у сфері господарювання: проблеми теорії і практики: монографія. Ніжин: ТОВ «Видавництво «Аспект-Поліграф», 2013. 504 с.
} 
facilitation of real insurance protection of the insured (natural persons and legal entities) and provide them with quality insurance services.

The second obligatory participant of a contractual insurance obligation is the insured. The insured are legal entities and legally capable natural persons who have concluded insurance contracts with insurers or are the insured in accordance with the current legislation (Part 2, Article 984 of the Civil Code of Ukraine, Article 3 of the Law of Ukraine "On Insurance"). Some scholars consider the insured as consumers of insurance services in contractual insurance relations and accordingly combine issues of exercise and protection of their rights with the exercise and protection of consumer rights. The adoption of the Concept for Protection of Rights of Consumers of Non-Banking Financial Services" by the Cabinet of Ministers of Ukraine contributed to this to a certain extent $^{37}$. A number of international legal instruments regulating consumer protection issues are adopted, in particular the Consumer Protection Charter, adopted by the 25th session of the Consultative Assembly of the European Union on May 17, 1973 (resolution 543) ${ }^{38}$ and "Guiding Principles for Protection of Consumer Interests", approved by The General Assembly of the United Nations on April 9, 1985 (resolution $39 / 248)^{39}$. The provisions of these international documents were reflected in the Law of Ukraine "On Protection of Consumer Rights" as well ${ }^{40}$.

In accordance with clause 22 of Article 1 of the Law of Ukraine "On Protection of Consumer Rights" a consumer is a natural person who purchases, orders, uses or intends to purchase or order products for personal needs not directly related to entrepreneurial activity or performance of duties of a hired employee.

It follows from this definition of the consumer that the consumer can be only a natural person - a person who is a participant in civil relations (thus, it can be both citizens of Ukraine, foreigners and stateless persons). However, the main criterion for distinguishing the consumer from other participants in civil legal relations is the goal of acquiring products aimed

\footnotetext{
${ }^{37}$ Про схвалення Концепції захисту прав споживачів небанківських фінансових послуг в Україні: Розпорядження Кабінету Міністрів України від 3.09.2009 р. № 1026-р. // Офіційний вісник України. 2009. № 69. С. 30 .

38 Дудла І. О. Захист прав споживачів: навчальний посібник. К.: Центр учбової літератури, 2007. C. 39.

39 Керівні принципи для захисту інтересів споживачів. Резолюція 39/248 Генеральної Асамблеї ООН від 09.04.1985 p. URL: http://zakon3.rada.gov.ua/laws/show/995_903 (дата звернення: 05.05.2019).

${ }^{40}$ Про захист прав споживачів: Закон України від 12.05.1991 р. // Відомості Верховної Ради УРСР. 1991. № 30. Ст. 379.
} 
at satisfying personal needs not directly related to entrepreneurial activity or performance of duties of a hired employee.

$\mathrm{O}$. Yu. Cherniak, studying the consumer's civil legal status in the context of Ukrainian legislation adaptation to the EU legislation, notes that in the legislation of some states the concept of "the consumer" is used without specifying any definitions, in other states this concept is introduced into legal terminology by judicial practice and/or legal doctrine. Within the framework of the EU there has been a separate concept of consumer rights protection, which can operate without reference to the right of EU member states. Taking into account the established judicial practice, the consumer is considered from the view of protection of a weaker party to the contract. Therefore, the consumer, in the EU law, is recognized as a person (not specified natural person or legal entity) who purchases goods (services) for use, but not for the purpose of personal commercial or professional activity ${ }^{41}$.

At the same time, interpretation of concept of a "consumer" as a natural person is not solely Ukrainian, but corresponds to the widespread European practice on this issue. Thus, according to Article 2 of Council Directive 93/13/EEC on 5 April, 1993 on unfair terms in consumer contracts, the consumer is any natural person who, in contracts governed by this Directive, is acting for purposes outside personal professional activity, business, and profession ${ }^{42}$. We should note that when comparing this definition with the definition of the Law of Ukraine "On Protection of Consumer Rights", granting a consumer status to a person does not depend on the nature of their actions performed, but in the Law the consumer must necessarily order, acquire, use something or intend to do so. Moreover, the Directive, unlike the Law, provides for a limited number of non-consumer goals, while all others are considered to be consumer ones. Therefore, according to the Directive, much more people will be subject to consumer protection. At present, there is no legal definition of the term "consumer of insurance services". Insufficient determinacy of the consumer legal status of insurance services creates obstacles in the protection of their rights. This is confirmed by judicial

\footnotetext{
${ }^{41}$ Черняк О. Ю. Цивільно-правовий статус споживача у контексті адаптації законодавства України до законодавства Свропейського Союзу: автореф. дис. ... канд. юрид. наук: 12.00.03; Науково-дослідний інститут приватного права і підприємництва Національної академії правових наук України. К., 2011. С. 7.

42 Директива Ради 93/13/ЄЕС від 5.04.1993 «Щодо несправедливих умов споживчих договорів // Міністерство юстиції України. URL: http://old.minjust.gov.ua/45878 (дата звернення: 05.05.2019).
} 
practice of considering civil cases arising from insurance contracts ${ }^{43}$. However, in accordance with paragraph 2 of the Resolution of the Plenum of the Supreme Court of Ukraine "On the practice of considering civil cases in claims for consumer rights protection", since the Law of Ukraine "On Protection of Consumer Rights" does not define certain limits of its validity, the courts should keep in mind that the relations, regulated by it, include in particular, those arising from insurance contracts ${ }^{44}$.

It should be noted that the consumer of insurance services, as it follows from the Law of Ukraine "On Protection of Consumer Rights", may not only be a natural person who acquires or orders a service for personal needs, but also a natural person who uses such service for these goals (for example, the insured person or beneficiary). Concluding an insurance contract in favor of the third person, the insured person is exactly the user (consumer) of the insurance service, provided that the insurance contract is aimed at satisfying their personal needs. Moreover, according to the letter from the Supreme Court of Ukraine of July 19, 2011, the insurance contract gives the third person the right to demand from the insurer to make an insurance payment in favor of this third person, that is, it gives the beneficiary the rights of the insured party, but does not impose on beneficiary obligations of the latter ${ }^{45}$. Therefore, it is appropriate to consider the consumer of insurance services as a capable natural person, who concludes an insurance contract with the insurer, as well as the natural person in whose interests and in whose favor the insurance contract is concluded, and who receives the insurance service necessary for satisfaction of personal needs, not directly related to the entrepreneurial activity of this natural person or the performance of natural person's duties as a hired employee.

The process of providing an insurance service combines the unity, confrontation and dependence of interests of the parties "insurer - the insured". This can be explained by necessity for a balance between ensuring the financial stability of the insurer on the one hand and

${ }^{43}$ Мельник 3. П., Романюк Я. М. Судова практика розгляду цивільних справ, що виникають 3 договорів страхування // Вісник Верховного Суду України. 2011. № 8(132). С. 12-28; Ханик-Посполітак Р. Ю. Захист прав споживачів фінансових послуг в Україні: правовий аналіз. К.: НУ «КиєвоМогилянська академія», 2011. 48 с.

44 Про практику розгляду цивільних справ за позовами про захист прав споживачів: затв. Постановою Пленуму Верховного Суду України від 12.04.1996 p. № 5. URL: http://zakon1.rada.gov.ua/laws/show/v0005700-96 (дата звернення: 05.05.2019).

45 Мельник 3. П., Романюк Я. М. Судова практика розгляду цивільних справ, що виникають 3 договорів страхування // Вісник Верховного Суду України. 2011. № 8 (132). С. 21. 
providing insurance protection to the insured, on the other. The insurers are interested in minimization of expenses, including at the expense of reduction of insurance payment, and the insured persons are interested in obtaining insurance protection in full. It is possible to add to these features as well that in most cases the consumer of insurance services does not have special knowledge in the field of providing this type of services. Therefore, as L. M. Sokil appropriately notes, it is unprofessional status of the consumer and asymmetry of the parties to the insurance contract that are those additional arguments determining the need for an additional protection mechanism of this category of the insured ${ }^{46}$.

The rights of consumers of insurance services, depending on the sources of legal regulation, can be classified into: 1) the rights enshrined in laws (the Civil Code of Ukraine, the Law of Ukraine "On Insurance", etc.), 2) the rights enshrined in by-laws (Decrees and Orders of the Cabinet of Ministers Ukraine, the Decree of the National Commission on State Regulation in the Field of Markets of Financial Services); 3) rights enshrined in local acts (Rules of Insurance); 4) rights enshrined in the insurance contract.

At the stage of concluding the contract, the consumer of insurance services has the right to necessary, available, reliable and timely information about the insurance service, ensuring the possibility of customer's informed and competent choice. Information must be provided prior to the purchase of a service. In addition, the right of consumer insurance services to information does not vanish after the conclusion of an insurance contract; it exists for the entire duration of the contract.

During the insurance contract validity, the consumer of insurance services has the right to: proper quality of service; the right not to disclose information about the customer and customer's property status, except in cases established by law; the right to renew the contract in case of reduction of the insurance risk or increase of the property value; the right of the insured to initiate the application amendments and additions to this agreement; the right to receive a duplicate of the insurance contract in case of its loss; the right to terminate the contract ahead of time in accordance with the conditions specified by the contract and Insurance

\footnotetext{
${ }^{46}$ Сокіл Л. М. Про необхідність уточнення поняття споживач страхових послуг // Фінанси, облік і аудит. 2012. № 19. С. 183.
} 
rules; the right to appoint beneficiaries to receive insurance payments or to change them before the occurrence of an insured event, etc.

After the insured event, the consumer of insurance services has the right to: timely receiving of insurance payments or insurance indemnity; the right to reimbursement of expenses incurred by the insured at the occurrence of an insured event in order to prevent or reduce losses, if it is provided by terms and conditions of the contract. In turn, in case of improper performance of the insurance contract, the consumer of insurance services has the right to judicial protection of violated, unrecognized or disputed rights or interests, the right to obtain a penalty (fine) in case of untimely obtaining of insurance payments, etc. In turn, the improper performance of the consumer insurance contract is the right to judicial protection of their violated, unrecognized or disputed rights or interests; the right to obtain a penalty (fine, fine) in case of untimely insurance payments, etc.

Therefore, considering the above mentioned, it should be noted that adaptation of Ukrainian legislation to the EU legislation under the conditions of Euro-integration processes in Ukraine will definitely contribute to the development of insurance service provision domain, taking into account the European experience and national peculiarities. Clear normative-legal basis meeting European standards is extremely necessary in provision of effective regulation of insurance relations, strengthening own institutions in the filed of insurance, increasing the standards of insurance service provision, ensuring the proper protection of customers' rights in insurance services etc. The understanding of significance and complexity of the process, successful use of approaches and methods of diversity of European legal field as well as taking into account the experience of the EU member states in this field will bring a necessary positive result.

Information about the author: Milovska N. V.

Candidate of Juridical Sciences, Assistant Professor at the Department of Special Legal Disciplines of the V. I. Vernadsky Taurida National University 